\title{
Protective assessment of cimetidine against cyclophosphamide-induced kidney injury
}

\author{
Bonsome Bokolo', Elias Adikwu² \\ Lecturer ${ }^{1}$ Department of Pharmacology, Faculty of Basic Medical Sciences, Niger Delta University, Nigeria, \\ Lecturer ${ }^{2}$ Department of Pharmacology and Toxicology, Faculty of Pharmacy, Niger Delta University, Nigeria
}

Background: Nephrotoxicity is one of the frequent toxicities observed with cyclophosphamide (CP) use which may involve oxidative stress. Cimetidine is an antihistamine with anti-oxidative stress activity. Aims and Objectives: The study aimed to evaluate the effect of cimetidine on cyclophosphamide-induced kidney damage in albino rats. Materials and Methods: Forty eight adult rats randomised into $8(\mathrm{~A}-\mathrm{H})$ groups of 6 rats per group were experimentally used for this study. Group A (control) was treated with water, while groups B-D were treated with 5,10 and $20 \mathrm{mg} / \mathrm{kg}$ of cimetidine intraperitoneally (ip) daily for 5 days respectively. Group E was treated with $150 \mathrm{mg} / \mathrm{kg}$ of CP ip on the $5^{\text {th }}$ day. Groups F-H were pretreated with 5,10 and $20 \mathrm{mg} / \mathrm{kg}$ cimetidine ip daily for 5 days and treated with CP ip on the $5^{\text {th }}$ day respectively. Rats were sacrificed serum was extracted from blood and evaluated for renal function markers, while kidneys were harvested and evaluated for oxidative stress markers and histology. Results: There were no significant effects $(p>0.05)$ on the body and kidney weights of CP-treated rats. However, impaired kidney functions in CP-treated rats were marked by significant $(\mathrm{p}<0.05)$ increases in creatinine, urea, uric acid, sodium, potassium, chloride, bicarbonate, and malondialdehyde levels when compared to control. On the other hand, significant $(p<0.05)$ decreases in superoxide dismutase, catalase, glutathione, glutathione peroxidase, total protein and albumin were obtained in CP-treated rats when compared to control. Necrotic changes were observed in the kidneys of CP-treated rats. However, CP-induced nephrotoxic effects were significantly $(p<0.05 ; 0.01)$ reversed in cimetidine pretreated rats. Conclusion: Cimetidine shows potential as adjunct remedy for cyclophosphamide associated nephrotoxicity.

Access this article online

Website:

http://nepjol.info/index.php/AJMS DOI: 10.3126/ajms.v9i6.20669 E-ISSN: 2091-0576 P-ISSN: 2467-9100

Key word: Cyclophosphamide; Kidney; Toxicity; Cimetidine; Prevention; Albino Rats

\section{INTRODUCTION}

Cancer is a serious health challenge with a cosmopolitan incidence. ${ }^{12}$ Treatment methods including the application of chemotherapy have been of tremendous therapeutic benefits in the reduction of morbidity and mortality associated with cancer. Cyclophosphamide (CP) is one of the commonly and most frequently used drugs in cancer chemotherapy. CP is an alkylating agent, belonging to the class of oxazaphosphorins. ${ }^{3}$ It is widely used in the treatments of various cancers, rheumatoid arthritis, systemic lupusery thematosus, multiple sclerosis, and as an immunosuppressant in organ transplantation. ${ }^{4}$ The anticancer effect of $\mathrm{CP}$ has been attributed to its two active metabolites (phosphoramide mustard and acrolein) produced through metabolic activation by hepatic microsomal cytochrome P450 mixed functional oxidase. ${ }^{5}$

These metabolites interfere with the growth of susceptible rapidly proliferating malignant cells by the inhibition of DNA duplication. The reactive metabolites of CP chemically alkylate DNA and protein and produce crosslinks, which are responsible for their cytotoxic effect. ${ }^{5}$ It is generally accepted that cancer cell death occurs as a result of the inhibition of DNA replication, as the interlinked strands do not allow separation of the two strands. ${ }^{6}$ However, the use of CP has been associated with the induction of nephrotoxicity characterised by tubular 
necrosis, tubular fibrosis and glomerular congestion. $\mathrm{CP}$-induced nephrotoxicity has been attributed to the activities of its two primary metabolites (phosphoramide mustard and acrolein). ${ }^{7}$ Phosphoramide mustard produces antineoplastic effect while acrolein is a highly reactive metabolite that is electrophilic in nature. ${ }^{8}$ Recent studies suggest that these metabolites can alter kidney redox status in favour of oxidants production leading to kidney biomolecular damage. This action has been correlated with altered serum markers of renal function and kidney histoarchitectural damage observed in $\mathrm{CP}$ treated rats ${ }^{9}$

Cimetidine is one of the most important H2-receptor antagonists. ${ }^{10}$ It is an inhibitor of Cytochrome P 450 enzyme which plays an important role in nephrotoxicity. Cimetidine has imidazole and cyano groups that inhibit cytochrome P-450 by interacting with the heme moiety, which represents an important source for iron during cell and tissue injury. ${ }^{11}$ Studies have also indicated that cimetidine is able to scavenge oxidative radicals suggesting that this effect may be related to its antioxidant activity. Cimetidine is able to effectively inhibit free radical generation in vivo and reduce oxidative damage in tissues. ${ }^{12}$ Furthermore, studies have reported possible beneficial effects of cimetidine in animal model of drug-induced toxicities. Therefore, the current study examined the effect of cimetidine on cyclophosphamide-induced kidney damage in albino rats.

\section{MATERIALS AND METHODS}

\section{Drugs and experimental animals}

Cyclophosphamide (Biochem Pharmaceutical Industries India)and cimetidine (Shandong Shenglu Pharmaceutical India) were used for this study. Dose selection: Cyclophosphamide $(150 \mathrm{mg} / \mathrm{kg})^{13}$ and cimetidine $(5,10$ and $20 \mathrm{mg} / \mathrm{kg}$ ) were used for this study. Forty eight (48) adult albino rats with average weight of $220 \mathrm{~g} \pm 5 \mathrm{~g}$ used for this study were obtained from the animal house of the Department of Pharmacology and Toxicology Madonna University, Elele, Rivers State. The rats were housed in 8 (A$\mathrm{H})$ cages of 6 rats per cage and were allowed to acclimatize for 2 weeks in a well-ventilated room, maintained at a room temperature of $28{ }^{\circ} \mathrm{C}$, under natural lighting condition. The rats were fed with standard rodent chow and given water ad libitum.

\section{Drug administration}

Group A was treated with water

Group B was treated with $5 \mathrm{mg} / \mathrm{kg}$ of cimetidine ip daily for 5 days

Group C was treated with $10 \mathrm{mg} / \mathrm{kg}$ of cimetidine ip daily for 5 days

Group D was treated with $20 \mathrm{mg} / \mathrm{kg}$ of cimetidine ip daily for 5 days

Group E was treated with $150 \mathrm{mg} / \mathrm{kg}$ of cimetidine ip on the $5^{\text {th }}$ day

Group $\mathrm{F}$ was treated with $5 \mathrm{mg} / \mathrm{kg}$ of cimetidine ip daily for 5 days + CP on the $5^{\text {th }}$ day

Group $\mathrm{G}$ was treated with $10 \mathrm{mg} / \mathrm{kg}$ of cimetidine ip daily for 5 days + CP on the $5^{\text {th }}$ day

Group $\mathrm{H}$ was treated with $20 \mathrm{mg} / \mathrm{kg}$ of cimetidine ip daily for 5 days + CP on the $5^{\text {th }}$ day

\section{Sacrifice of animals}

After the completion of 5 days of drug administration, on the $6^{\text {th }}$ day the rats in all groups were sacrificed by ether inhalation. Blood was collected by intracardiac puncture, and centrifuged at $3000 \mathrm{rpm}$ for $15 \mathrm{~min}$. The serum was collected and used for the estimation of serum renal function biomarkers. Kidney of each rat was isolated, separated from their surrounding connective tissues, washed and cleaned with normal saline solution. Renal tissues were blotted using filter paper, weighed and rinsed in ice-cold saline. The kidney was homogenized for endogenous antioxidants analysis.

\section{Evaluation of renal function parameters}

Serum creatinine, urea, uric acid, albumin, total protein and bicarbonate were measured using standard laboratory test kits.Sodium, potassium, and chloride were evaluated as reported by Olurishe et al., 2012 14

\section{Evaluation of oxidative stress indices}

Kidney protein was evaluated as reported by Gornall et al., $1945^{15}$ whereas superoxide dismutase was determined according to Sun and Zigman 1978. ${ }^{16}$ Catalase was assayed according to Aebi $1984^{17}$ whereas reduced glutathione was estimated as described by Sedlak and Lindsay (1968). ${ }^{18}$ Malondialdehyde was determined using the method of Buege and Aust $1978^{19}$ whereas glutathione peroxidase was determined according to Rotruck et al., $1973^{20}$

\section{Histological examination of the kidney}

Kidneys were fixed in 10\% formalin for at least $24 \mathrm{~h}$. Then, kidney tissues were dehydrated with a sequence of ethanol solutions, embedded in paraffin, cut into $5 \mu \mathrm{M}$ sections and stained with Hematoxylin and Eosin dye. The stained sections were evaluated for pathology using a light microscope.

\section{Statistical analysis}

Data was analysed using SPSS 18 software (SPSS Inc, Chicago, IL). Results are expressed as mean \pm standard error of mean (SEM). Mean differences were established using ANOVA followed by Tukey's post hoc test. Values of $p<0.05$; 0.01 were considered significant 


\section{RESULTS}

In the current study, treatment with 5,10 and $20 \mathrm{mg} / \mathrm{kg}$ of cimetidine did not produce significant $(p>0.05)$ effects on serum renal function parameters and kidney oxidative stress indices when compared to control (Table 1-4). Treatment with $150 \mathrm{mg} / \mathrm{kg}$ of CP had no significant $(\mathrm{p}>0.05)$ effects of on the body and kidney weights of albino rats when compared to control (Table 1). However, the present study observed significant $(\mathrm{p}<0.05)$ increases in serum creatinine, urea and uric acid whereas serum albumin and total protein were significantly $(\mathrm{p}<0.05)$ decreased in rats treated with CP when compared to control (Table2). Interestingly, significant $(\mathrm{p}<0.05 ; 0.01)$ decreases in serum creatinine, urea and uric acid with significant $(\mathrm{p}<0.05 ; 0.01)$ increases in serum albumin and total protein were observed in rats pretreated with cimetidine in a dose-dependent manner (Table 2). Furthermore, the administration of CP produced significant $(\mathrm{p}<0.05)$ effects on $\mathrm{K}+, \mathrm{Cl}-, \mathrm{Na}+$ and $\mathrm{HCO} 3-$ levels when compared to the levels of these parameters in the control group. However, this study observed that the serum levels of $\mathrm{K}^{+}, \mathrm{Cl}^{-}, \mathrm{Na}^{+}$and $\mathrm{HCO} 3$ - were significantly $(\mathrm{p}<0.05)$ restored in a dose-dependent manner in cimetidine pretreated rats (Table 3). The kidney levels of CAT, GSH, SOD and GPX were significantly $(\mathrm{p}<0.05)$ decreased whereas MDA levels were significantly $(p<0.05)$ increased in CP-treated rats in comparison to control (Table 4). Interestingly, pretreatment with cimetidine significantly $(\mathrm{p}<0.05 ; 0.01)$ increased kidney levels of CAT, GSH, SOD and GPX whereas MDA levels were significantly $(\mathrm{p}<0.05 ; 0.01)$ decreased in a dose-dependent manner (Table 4). The kidneys of the control rat and rats treated with 5,10 and $20 \mathrm{mg} / \mathrm{kg}$ of cimetidine showed normal histology (Figure 1a-d). However, the kidney of $150 \mathrm{mg} /$ $\mathrm{kg}$ of CP-treated rat showed dilated tubules, tubular necrosis, interstitial edema and infiltration of interstitium by inflammatory cells (Figure 1e). Also, the kidney of rat treated with $5 \mathrm{mg} / \mathrm{kg}$ of cimetidine and $150 \mathrm{mg} / \mathrm{kg}$ of CP showed dilated tubules, tubular necrosis, interstitiale dema with infiltration of interstitium by inflammatory cells (Figure 1f). Furthermore, the kidney of rats treated with $10 \mathrm{mg} / \mathrm{kg}$ of cimetidine and $150 \mathrm{mg} / \mathrm{kg}$ of CP showed tubular necrosis (Figure 1g). Also, the kidney of rat treated with $20 \mathrm{mg} / \mathrm{kg}$ of cimetidine and $150 \mathrm{mg} / \mathrm{kg}$ of CP showed tubular necrosis (Figure 1h).

\section{DISCUSSION}

Cyclophosphamide (CP) is an alkylating agent used as an immunosuppressant in rheumatoid arthritis and in the treatment of several cancers. ${ }^{21}$ One of the most common limitations of the use of CP is nephrotoxicity. $\mathrm{CP}$ is associated with the induction of tubular necrosis, tubular fibrosis, glomerular congestion and inflammation, thereby causing renal dysfunction. ${ }^{22}$ Treatment with CP and cimetidine did not produce significant effects on body and kidney weights. Renal biochemical markers play important

\section{Table 1: Effect of cimetidine on body and kidney weights of cyclophosphamide- treated albino rats}

\begin{tabular}{lccc} 
Dose $(\mathbf{m g} / \mathbf{k g})$ & Initial body weight $(\mathbf{g})$ & Final body weight $(\mathbf{g})$ & Kidney weight $(\mathbf{g})$ \\
\hline Control & $226.6 \pm 14.9$ & $235.6 \pm 15.6$ & $1.23 \pm 0.03$ \\
CD 5 & $207.8 \pm 17.4$ & $215.8 \pm 14.0$ & $1.02 \pm 0.02$ \\
CD 10 & $209.6 \pm 14.7$ & $217.0 \pm 13.8$ & $1.05 \pm 0.06$ \\
CD 20 & $219.8 \pm 15.6$ & $225.4 \pm 17.9$ & $1.03 \pm 0.02$ \\
CP 150 & $214.6 \pm 10.8$ & $207.6 \pm 15.1$ & $1.06 \pm 0.04$ \\
CD 5+CP & $217.6 \pm 17.9$ & $213.0 \pm 14.4$ & $1.11 \pm 0.03$ \\
CD 10+CP & $232.4 \pm 12.6$ & $228.6 \pm 12.1$ & $1.13 \pm 0.03$ \\
CD 20+CP & $211.2 \pm 14.3$ & $206.6 \pm 15.7$ & $1.23 \pm 0.01$ \\
\hline
\end{tabular}

$\mathrm{CD}=$ Cimetidine, $\mathrm{CP}=$ Cyclophosphamide, values are expressed as Mean $\pm S E M, n=6$

Table 2: Effect of cimetidine on renal function parameters of cyclophosphamide- treated albino rats

\begin{tabular}{|c|c|c|c|c|c|}
\hline Dose (mg/kg) & Urea mg/dL & Creatinine $\mathrm{mg} / \mathrm{dL}$ & Uric acid mg/dL & Total protein $\mathrm{mg} / \mathrm{dL}$ & Albumin $\mathrm{mg} / \mathrm{dL}$ \\
\hline Control & $33.3 \pm 3.00$ & $1.41 \pm 1.08$ & $1.34 \pm 1.11$ & $7.90 \pm 1.61$ & $3.69 \pm 0.34$ \\
\hline CD 5 & $30.4 \pm 3.30$ & $1.40 \pm 1.02$ & $1.33 \pm 1.09$ & $7.64 \pm 0.58$ & $3.47 \pm 0.39$ \\
\hline CD 10 & $32.6 \pm 2.02$ & $1.38 \pm 0.15$ & $1.31 \pm 0.31$ & $7.59 \pm 0.50$ & $3.55 \pm 0.44$ \\
\hline CD 20 & $30.7 \pm 2.73$ & $1.69 \pm 0.04$ & $1.30 \pm 0.25$ & $7.53 \pm 0.47$ & $3.50 \pm 0.40$ \\
\hline CP 150 & $120.5 \pm 7.80^{a}$ & $3.19 \pm 0.13^{a}$ & $3.71 \pm 0.13^{a}$ & $2.43 \pm 0.22^{a}$ & $0.74 \pm 0.17^{a}$ \\
\hline CD 5+CP & $88.1 \pm 6.38^{b}$ & $2.68 \pm 0.15^{b}$ & $2.98 \pm 0.20^{\mathrm{b}}$ & $3.05 \pm 0.17^{b}$ & $1.19 \pm 0.19^{b}$ \\
\hline$C D 10+C P$ & $65.7 \pm 3.96^{b}$ & $2.06 \pm 0.90^{b}$ & $2.23 \pm 0.22^{b}$ & $4.15 \pm 0.24^{b}$ & $2.00 \pm 0.11^{b}$ \\
\hline
\end{tabular}

$\mathrm{CD}=$ Cimetidine, $\mathrm{CP}=$ Cyclophosphamide, values are expressed as Mean $\pm S E M, n=6$, asignificant $(\mathrm{p}<0.05)$ difference when compared to control, bSignificant ( $\mathrm{p}<0.05$ ) difference when compared to CP-treated rats, 'Significant $(p<0.01)$ difference when compared to $C P$-treated rats 


\begin{tabular}{lcccc}
\multicolumn{4}{l}{ Table 3: Effect of cimetidine on serum electrolytes of cyclophosphamide-treated albino rats } \\
\hline Dose $(\mathbf{m g} / \mathbf{k g})$ & $\mathbf{K}^{+} \mathbf{m m o l} / \mathbf{L}$ & $\mathbf{C L}^{-} \mathbf{m m o l} / \mathbf{L}$ & $\mathbf{N a}^{+} \mathbf{m m o l} / \mathbf{L}$ & HCO3- $\mathbf{~ m m o l} / \mathbf{L}$ \\
\hline Control & $4.79 \pm 0.46$ & $149.5 \pm 13.1$ & $128.6 \pm 23.1$ & $27.6 \pm 2.10$ \\
CD 50 & $4.83 \pm 0.49$ & $150.7 \pm 6.72$ & $130.1 \pm 18.6$ & $29.2 \pm 4.78$ \\
CD 10 & $4.80 \pm 0.50$ & $152.5 \pm 9.78$ & $129.9 \pm 10.8$ & $28.0 \pm 3.07$ \\
CD 20 & $4.82 \pm 0.45$ & $153.6 \pm 18.4$ & $131.0 \pm 12.1$ & $30.5 \pm 2.62$ \\
CP 150 & $1.22 \pm 0.15^{\mathrm{a}}$ & $50.9 \pm 6.56^{\mathrm{a}}$ & $60.6 \pm 9.79^{\mathrm{a}}$ & $10.5 \pm 0.07^{\mathrm{a}}$ \\
CD 5+CP & $2.88 \pm 0.11^{\mathrm{b}}$ & $70.4 \pm 5.63^{\mathrm{b}}$ & $84.6 \pm 11.2^{\mathrm{b}}$ & $15.7 \pm 0.88^{\mathrm{b}}$ \\
CD 10+CP & $3.42 \pm 0.27^{\mathrm{c}}$ & $95.7 \pm 9.91^{\mathrm{b}}$ & $100.9 \pm 10.4^{\mathrm{b}}$ & $22.6 \pm 4.11^{\mathrm{c}}$ \\
CD 20+CP & $4.04 \pm 0.74^{\mathrm{c}}$ & $144.3 \pm 18.0^{\mathrm{c}}$ & $118.6 \pm 15.2^{\mathrm{c}}$ & $28.0 \pm 1.24^{\mathrm{c}}$ \\
\hline
\end{tabular}

$C D=$ Cimetidine, $C P=C y c l o p h o s p h a m i d e$, values are expressed as Mean $\pm S E M, n=6$, aSignificant ( $p<0.05)$ difference when compared to control, ${ }^{b}$ Significant ( $p<0.05$ ) difference when compared to CP-treated rats, 'Significant $(p<0.01)$ difference when compared to CP-treated rats.

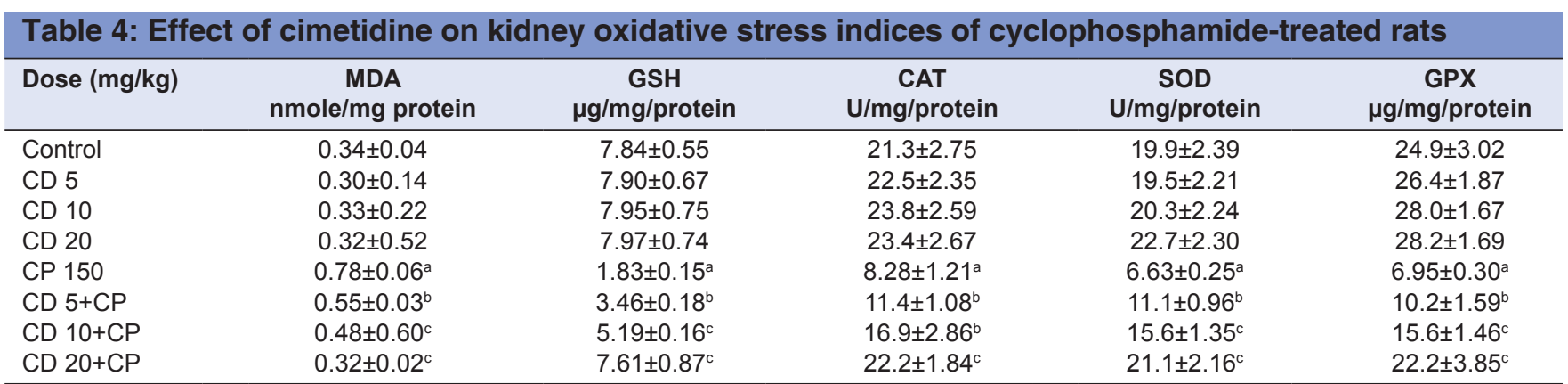

$C D=$ Cimetidine, $C P=C y c l o p h o s p h a m i d e$, values are expressed as Mean $\pm S E M, n=6$, asignificant $(p<0.05)$ difference when compared to control, ${ }^{b} S i g n i f i c a n t$ ( $p<0.05$ ) difference when compared to CP-treated rats, 'Significant $(p<0.01)$ difference when compared to CP-treated rats.

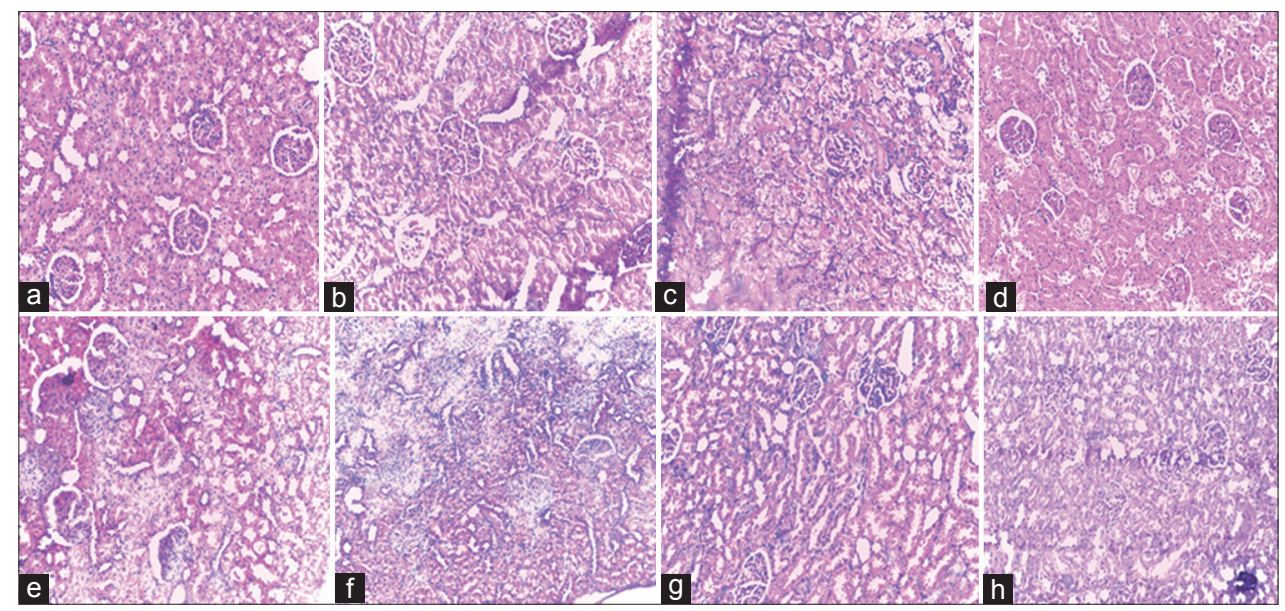

Figure 1: (a) Kidney of control rat treated with water showing normal histology. (b-d) Kidneys of rats treated with cimetidine 5, 10, $20 \mathrm{mg} / \mathrm{kg}$ daily for 5 days showing normal histology. (e) Kidney of rat treated with $150 \mathrm{mg} / \mathrm{kg}$ of cyclophosphamide showing dilated tubules with necrosis, interstitial edema with infiltration of interstitium by inflammatory cells. (f) Kidney of rat treated with $150 \mathrm{mg} / \mathrm{kg}$ of cyclophosphamide showing dilated tubules with necrosis, interstitial edema with infiltration of interstitium by inflammatory cells. (g) Kidney of rat treated with $10 \mathrm{mg} / \mathrm{kg}$ of cimetidine and $150 \mathrm{mg} / \mathrm{kg}$ of cyclophosphamide showing tubular necrosis. (h) Kidney of rat treated with $10 \mathrm{mg} / \mathrm{kg}$ of cimetidine and $150 \mathrm{mg} / \mathrm{kg}$ of cyclophosphamide showing tubular necrosis ( $\mathrm{H}$ and Ex 200)

roles in accurate diagnosis of real diseases. Instead of urine analysis which is relatively discomforting for patients, serum analysis of renal function markers which include urea creatinine, uric acid and electrolytes are used routinely. ${ }^{23}$ In the current study, evaluation of the serum levels of creatinine, urea and uric acid in CP-administered rats showed higher levels above normal. This observation is a common feature of $\mathrm{CP}$ associated nephrotoxicity. ${ }^{24}$ The increase in serum levels of these parameters after $\mathrm{CP}$ administration may be due to reduction in glomerular filtration rate and renal excretion of these parameters. ${ }^{25}$ However, serum levels of creatinine, urea and uric acid were restored in a doses-dependent manner in rats pretreated with cimetidine. Electrolytes are positively and negatively charged ions that are found within cells and extracellular fluids. Electrolytes evaluation includes the measurement of sodium, potassium, chloride, and bicarbonate. These ions are measured to assess kidney function. ${ }^{26}$ Serum electrolytes are the keys to 
homeostasis and their regulation depend on renal function. Kidney disease is associated with aberrations in the regulation of serum electrolytes. ${ }^{27}$ This study observed altered levels of serum electrolytes in CP-treated rats. This is consistent with observations reported by some authors. ${ }^{28}$ In contrast; the serum levels of electrolytes were restored in a dosedependent manner in rats pretreated with cimetidine. CP renal pathology could be associated with necrotic changes in the histo-architecture of the kidney. Studies have reported atrophy of glomerular tuft, tubular necrosis, dilation, edema and congestion of renal blood vessels. ${ }^{29}$ The finding in this study showed tubular necrosis, edema and inflammatory cells infiltration in the kidneys of CP-treated rats. However, necrotic changes were ameliorated in cimetidine pretreated rats.

According to Park et al. (2013) ${ }^{30}$ oxidative stress mediates a wide range of renal impairments through oxidative radical production and antioxidant depletions. Superoxide dismutase (SOD) is the first antioxidant enzyme to deal with oxy-radicals by accelerating the dismutation of superoxide to hydrogen peroxide. Catalase (CAT) is a peroxisomal hem protein that catalyzes the removal of hydrogen peroxide formed during the reaction catalyzed by SOD. Thus, SOD and CAT act as mutually supportive antioxidants that provide defence against oxidative radicals. ${ }^{31}$ Glutathione (GSH) is a major constituent of the detoxification pathway. The amino acid constituent of GSH (cysteine) is regarded as part of the first line of defence and neutralizes oxidative radicals and plays an important role against inflammation and oxidative stress. ${ }^{32}$ Studies suggest the role of oxidative stress in CP-induced renal toxicity and it is often accompanied by depletions and decreases in antioxidant activities. ${ }^{33}$ The current study observed depletions in antioxidant activities characterised by lower levels of SOD, CAT GSH and GPX in the kidneys of CP-treated rats. However, depletions were inhibited and the activities of these antioxidants were upregulated in cimetidine pretreated rats. Lipid peroxidation is a free radical stimulated oxidative destruction of poly unsaturated fatty acid. It is the product of the reaction of free radicals with lipids that is considered as an integral feature of xenobiotic-induced renal injury. ${ }^{34}$ Malondialdehyde (MDA) is one of end products of lipid peroxidation and is used to access lipid peroxidation and free radical generation. ${ }^{35}$ In consonance with finding by Golshahiet al., $2018^{36}$ the present study, observed lipid peroxidation marked by elevated kidney levels of MDA in CP-treated rats. However, there was decrease in lipid peroxidation marked by low levels of MDA in cimetidine pretreated rats.

The mechanism by which CP causes kidney damage is not well understood, but studies have attributed it to its cytotoxic metabolites; phosphoramide mustard and acrolein. Phosphoramide mustard has antineoplastic activity while acrolein, is a highly reactive metabolite that can induce oxidative stress. ${ }^{37}$ Furthermore, Abraham et al., (2009) ${ }^{38}$ reported that $\mathrm{CP}$ - induced renal damage may be due to nitrosative stress. Also, CP can induce the production of TNF- $\alpha$ in renal tissues. TNF- $\alpha$ is a pleiotropic cytokine that can induce cell death via apoptosis and necrosis pathway. ${ }^{39}$ In the present study, the observed ameliorative effect of cimetidine could be attributed to its ability to inhibit CP-induced oxidative and nitrosative stress in renal tissues of treated rats. Cimetidine has the ability to scavenge free radicals, up-regulate antioxidant activities and inhibits the production of pro-inflammatory mediators. ${ }^{40} \mathrm{Also}$, as an inhibitor of hepatic enzyme, cimetidine might have prevented the biotransformation of $\mathrm{CP}$ to its toxic metabolites by hepatic enzymes.

\section{CONCLUSION}

Cimetidine ameliorates cyclophosphamide-induced renal toxicity in albino rats.

\section{ACKNOWLEDGMENTS}

The authors kindly appreciate the assistance rendered by Nwachukwu Irene Ngozichukwu of the Faculty of Pharmacy Madonna University, Elele, Rivers State

\section{REFERENCES}

1. Gmeiner WH and Ghosh S. Nanotechnology for cancer treatment. Nanotechnol Rev 2015; 3: 111-122.

2. Nussbaumer $\mathrm{S}$, Bonnabrya $\mathrm{P}$, Veuthey $\mathrm{J}$ and Fleury-Souverain $\mathrm{S}$. Analysis of anticancer drugs: A review. Talanta 2011; 85: 2265-2289.

3. Oh MS, Chang MS, Park W, Kim DR, Bae H, Huh Y, et al. Yukmijihwang-tang, protects against cyclophosphamideinduced reproductive toxicity. ReprodToxicol 2007; 24: 365-370.

4. Teles AK, Medeiros-Souzaa P, Limac FA, Araújo BG and Limae RA.Cyclophosphamide administration routine in autoimmune rheumatic diseases: A review. Rev Bras de Reumatol 2017;57:596-604.

5. Hales BF. Comparison of the mutagenicity and teratogenicity of cyclophosphamide and its active metabolites, 4-hydroxycyclo phosphamide, phosphoramide mustard, and acrolein. Cancer Res 1982; 42:3016-3021.

6. Schwartz PS and Waxman DJ. Cyclophosphamide induces caspase 9-dependent apoptosis in 9L tumor cells. MolPharma 2001; 60: 1268-1279.

7. Abraham $P$ and Rabi S. Protective effect of aminoguanidine against cyclophosphamide-induced oxidative stress and renal damage in rats. Red Rep 2011; 16(1):8-14.

8. Senthilkumar S, Yogeeta SK, Subashini R and Devaki T. Attenuation of cyclophosphamide induced toxicity by squalene in experimental rats. ChemBiol Interact 2006; 160: 252-260.

9. Bhattacharya A, Lawrence RA, Krishnan A, Zaman K, Sun D and Fernandes G. Effect of dietary n-3 and n-6 oils with and without food restriction on activity of antioxidant enzymes 
and lipid peroxidation in livers of cyclophosphamide treated autoimmune-prone NZB/W female mice. Jour of AmerColl of Nutri 2003; 22: 388-399.

10. Rang HP, Dale MM and Ritter JM. The gastrointestinal tract. In: Pharmacology, $3^{\text {rd }}$ edition, Churchill Livingstone, New York. 1995;389.

11. Paller MS and Hedlund BE. Role of iron in postischemic renal injury in the rat. Kidney Int 1988; 34: 474-480.

12. Lapenna D, De Gioia S, Mezze'iti A, Grossi L and Festi D. H2 receptor antagonists are scavengers of oxygen radicals. Euro Jour of Clin Invest 1994; 7:476-481.

13. Abraham $P$ and Isaac $B$. The effects of oral glutamine on cyclophosphamide-induced nephrotoxicity in rats. Hum ExpToxicol 2011; 30; 7: 616-623.

14. Olurishe TO, Kwanashie HO, Anuka JA, Muktar HM and Sambo JC. Renal impact of subacute lamivudine-artesunate treatment in wistar rats Afr J PharmacolTher 2013; 2: 48-53.

15. Gornall AG, Bardawill CJ and David MM. Determination of serum proteins by means of the biureto reaction.J BiolChem 1949; 177: 751-766.

16. Sun M and Zigma S. An improved spectrophotometer assay of superoxide dismutase based on epinephrine antioxidation. Anal Biochem 1978; 90: 81-89.

17. Aebi H. Catalase in vitro, in Method in Enzymology, SP Colowick and N O Altman, D. F: Drugs used in gastrointestinal diseases. In: B. G. Katzung. (Ed.), Basic and Clinical Pharmacology, $7^{\text {th }}$ edition, Appleton and Lange Medical Publisher, Connecticut, USA. 1998; 1019-1020.

18. Sedlak $J$ and Lindsay RH. Estimation of total, protein-bound and non-protein sulfhydryl groups in tissue with Ellman's reagent. Anal Biochemistry 2007; 25: 192-205.

19. Buege JA and Aust SD. Microsomal lipid peroxidation. Meth Enzy 1978; 52: 302-310.

20. Rotruck JT, Rope AL, Ganther HF and Swason AB. Selenium: biochemical role as a component of glutathione peroxidase. Sci 1973; 179: 588-590.

21. Rehman MU, Tahir M, Ali F, Qamar W, Lateef A, Khan R, et al. Cyclophosphamide-induced nephrotoxicity, genotoxicity, and damage in kidney genomic DNA of Swiss albino mice: the protective effect of Ellagic acid. Mol Cell Biochem 2012;365:119-127.

22. Singh $M$, Kumar $N$, Shuaib $M$, Garg VK and Sharma $A$. A review on renal protective agents for cyclophosphamide induced nephrotoxicity. Jour Pharm PharmSci 2014; 3: 737-447.

23. Gowda S, Desai PB,Kulkarni SS, Hull VV, Math AAK and Vernekar SN. Markers of renal function tests. N Am J Med Sci 2010;2:170-173.

24. Estakhri R, Hajipour B, Majidi $H$ and Soleimani H. Vitamin E ameliorates cyclophosphamide induced nephrotoxicity. Life Sci J 2013;10:308-313.

25. Vaziri ND, Freel RK and Hatch M. Effect of chronic experimental renal insufficiency on urate metabolism. J AmSocNephrol 1995; 6:1313-1317.
26. Yousafzai A, Ara S, Javed F, Jahan N, Ahmed N, Waseem M, et al. Kidney function tests and serum electrolyte disorders in different ethnic groups of Balochistan. Jour of Appl and EmerSci2011; 2:164-170.

27. Owiredu WKA, Ephraim RKD, Eghan BAJ, Nafiu A and Edwin FL. Relationship between parathyroid hormone and electrolytes in chronic kidney disease. E3 Jour of Med Res 2012; 1: 103-111.

28. Elazzazy S, Mohamed AE and Gulied A. Cyclophosphamideinducedsymptomatic hyponatremia, a rare but severe side effect: a case report. Onco Targets Ther 2014; 7: 1641-1645.

29. Amien A, Sohair R,Fahmy B, Fathi M,Abd-Elgleel C, Sara M, et al. Renoprotective effect of Mangiferaindica polysaccharides and silymarinRenoprotective effect of Mangiferaindica polysaccharides and silymarin against cyclophosphamide toxicity in rats. The Jour of Basic \&ApplZool 2015; 72: 154-162.

30. Park S, Kim CS, Lee J and Kim J. Effect of regular exercise on the histochemical changes of d-galactose-induced oxidative renal injury in high-fat diet-fed rats. ActaHistochemCytochem 2013; 46: 111-119.

31. Jayaraman T, Kannappan S, Ravichandran SM and Anuradha CV. Impact of Essentiale L on ethanol-induced changes in rat brain and erythrocytes.Singapore Med J 2008; 49: 320-327.

32. Circu ML and Aw TY. Redox biology of the intestine. Free Radic Res 2011; 45: 1245-1266.

33. Haque R, Bin-Hafeez B, Parvez S, Pandey S, Sayeed I, Ali M, et al. Aqueous extract of walnut (Juglansregia L.) protects mice against cyclophosphamide-induced biochemical toxicity. Hum ExpToxicol 2003; 22:473-480.

34. Hoek JB and Pastorino JG. Ethanol, oxidative stress, and cytokine induced liver damage. Alc 2002; 27: 63-68.

35. Jnaneshwari S, Hemshekhar M,Santhosha MS, Sunitha K, Thushara R, Thirunavukkarasu $\mathrm{C}$, et al. A dietary colorant mitigates cyclophosphamide-induced organ toxicity by modulating antioxidant status and inflammatory cytokines Pharm. Pharmacol 2012; 65: 604-614.

36. Golshahi $\mathrm{H}$, Baghban $\mathrm{F}$ and Tabari MAJ. Ameliorative action of farnesol on cyclophosphamide induced toxicity in mice. HerbmedPharmacol 2018; 7: 37-43.

37. Honjo T. Suou and Hirayama C. Hepatotoxicity of cyclophosphamide in man: pharmacokinetic analysis. Res Comm in Chem Path and Pharm 1988; 61; 2:149-165.

38. Abraham P, IndiraniKand SugumarE. Effect of cyclophosphamide treatment on selected lysosomal enzymes in the kidney of rats. ExpToxicolPathol 2007;59:143-149.

39. Wu X, Guo R, Chen P, Wang $Q$ and Cunningham PN. TNF induces caspase-dependent inflammation in renal endothelial cells through a Rho and myosin light chain kinase dependent mechanism. Am J Physiol Renal Physiol 2009; 297: 316-326.

40. Ching T, Haenen GM and Bast A. Cimetidine and other $\mathrm{H}_{2}$ receptor antagonists as powerful hydroxyl radical scavengers. Chem Bio Inter 1993; 86(2):119-127.

\section{Authors Contribution:}

EA-Concept and design of the study, literature search, collection of data, statistical analysis, manuscript preparation and critical revision of the manuscript; BB-Concept, collection of data, review of literature, preparation of first manuscript draft and critical revision of the manuscript

\section{Work attributed to:}

Department of Pharmacology, Faculty of Basic Medical Sciences, Niger Delta University, Nigeria

Orcid ID:

Dr.Adikwu Elias- (1) https://orcid.org/0000-0003-4349-8227

Dr.Bonsome Bokolo- D https://orcid.org/0000-0001-6426-6228

Source of Support: Nil, Conflict of Interest: None declared. 